Volume 13 Number 2, April-June 2019: pp. 187-208. Copyright (c) 2019 FIAT JUSTISIA. Faculty of Law, Lampung University, Bandarlampung, Lampung, Indonesia. ISSN: 1978-5186 | e-ISSN: 2477-6238.Open Access: http://jurnal.fh.unila.ac.id/index.php/fiat

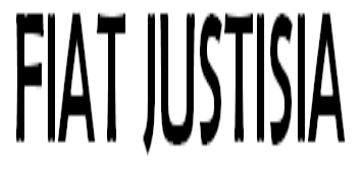

Fiat Justisia is licensed under a Creative Commons Attribution 4.0 International License, which permits unrestricted use, distribution, and reproduction in any medium, provided the original work is properly cited.

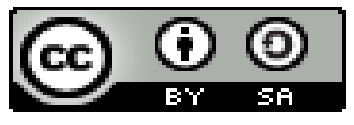

\title{
Legal Policy Model for Prevention Children Marriage at West Nusa Tenggara Province
}

\author{
Sri Karyati \\ Faculty of Law Islamic University of Al-Azhar Mataram, Indonesia \\ srikaryati84@gmail.com \\ B. Farhana K.Lestari \\ Faculty of Law Islamic University of Al-Azhar Mataram, Indonesia \\ baiqfarhanakurnialestari@gmail.com
}

\begin{abstract}
Until now, the issue of child marriage in NTB has not yet been resolved. The issue of child marriage in NTB has not been completed because the roots of child marriage in NTB have not touched the root of the real problem. Therefore there must be a more comprehensive policy breakthrough to prevent the prevention of child marriage in NTB. There is a need for a legal policy to prevent child marriages in NTB that needs scientific studies as the basis for scientific legitimacy about the urgency of the existence of regional regulations to prevent child marriage. There are two problems in this research: first, what is the juridical problem in the policy of preventing the occurrence of child marriage in NTB? Second, what are the right and applicable policy model in preventing the occurrence of child marriage in NTB? This research is normative legal research with a focus on evaluating the policy of preventing child marriage that has been taken by the NTB provincial government. The research approach used is a normative approach and an empirical approach.

The results showed that the first, juridical barriers to preventing child marriage in NTB not only had juridical obstacles in terms of the validity of the provisions of article 7 paragraph (1) of the marriage law that regulates the minimum age of marriage is 16 years for women, but also still has obstacles juridical relating to the legal policy on the regulation of child marriages in the content of regional regulations because the local regulation
\end{abstract}


must not conflict with article 7 paragraph (1) of the marriage law which is still valid and other constraints are not operational and the effective decision of the constitutional court No. 22 / PUU / XV / 2017 concerning judicial review of Law No. 1 of 1974 concerning Marriage because this decision only delayed the implementation of the Constitutional Court's decision in 2021 and was very dependent on legislative policy from the DPR and the President to amend Law No. 1 of 1974 concerning Marriage according to the order of the Constitutional Court's decision. Second, the appropriate and applicable policy model in preventing the occurrence of child marriages in NTB is done using the transitional policy model and posttransition policy. The transition policy is carried out by making regulations that regulate the prevention of child marriages by using the child protection paradigm, while post-transition policies are carried out using the family quality policy paradigm with a focus on increasing the age of marriage, legislation. First, the Republic of Indonesia Parliament, especially the Republic of Indonesia Parliament for the period 2019-2024 and the President should immediately follow up on Decision No. 22 / PUU / XV / 2017 by taking legislative policies by entering the amendment bill to Law No. 1 of 1974 concerning Marriage into a national legislation program which is subsequently compiled, discussed and stipulated as law. Second, to respond to the dynamic dynamics of marital law and child protection, the NTB Governor and the NTB DPRD should immediately take legislation in the regions by including the draft regulation on the prevention of child marriages in the 2019 local regulation formation program and then compile and discuss it into regional regulations.

Keywords: Legal Policy, Children Marriage, Local Regulation

How to Cite: Sri Karyati and B. Farhana K.Lestari, "Legal Policy Model for Prevention Children Marriage at West Nusa Tenggara Province", Fiat Justisia, 13 (2), (2019).

DOI: https://doi.org/10.25041/fiatjustisia.v13no2.1673

\section{A. Introduction}

One of the population and family planning programs currently faced by the local government is the marriage by its citizens. Based on data submitted by BKKBN NTB, in 2015, the rate of child marriages in NTB reached $5.81 \%$. This figure places NTB as the province with the second highest level of child marriage after West Java Province. The high number of child marriages in NTB turned out to have an impact on the high divorce rate, based on data held by the NTB BKKBN Representative in 2015, the NTB 
divorce rate reached $21.55 \%$. Child marriage also affects the violation of the right of adolescents to get proper education ${ }^{1}$ because they cannot continue their education even to high school.

The condition of the rise of child marriages then contributed to the still low numbers of the NTB Human Development Index (HDI). The results of the release of the 2014 Central Bureau of Statistics (BPS) survey placed the Human Development Index (HDI) of West Nusa Tenggara (NTB) Province at number 33 of the 34 provinces surveyed. The NTB HDI is only one click above Papua and below West Papua. This result is not much different from the BPS survey several years earlier. Since it was first published by BPS the ranking of HDI-NTB number 26 from 27 provinces (1996-1999) with a value of 56.7 and 54.2 respectively. In 2002 it ranked 30th out of 30 provinces with a value of 57.8 and from 2005 to 2011 always at position 32 with a value 62,42 (2005), 63,04 (2006), 63,71 (2007), 64,12 (2008), 64,66 (2009), 65,2 (2010), 66,23 (2011), in 2012-2013 the NTB HDI was in position 33 of 34

Province. $^{2}$

If the phenomenon of child marriage cannot be stopped, it will have an impact on the low quality of the population of NTB. Besides that, it will complicate the achievement of the objectives of law number 52 of 2009 concerning population development and family development. Even though the purpose of the enactment of law number 52 of 2009 concerning population development and family development to create harmony and balance between the quantity, quality and distribution of the population and the environment. Family development aims to improve the quality of the family so that a sense of security, peace and hope for a better future can arise in realising birth and inner happiness. The NTB provincial government took the child marriage prevention policy by issuing a Circular Letter from the governor of NTB number 150/1138 / Kum about the maturity of the marriage age. But until now, child marriage issues in NTB have not yet been resolved. The issue of child marriage in NTB has not been completed because the roots of child marriage in NTB have not touched the root of the real problem. Therefore there must be a more comprehensive policy breakthrough to prevent child marriage in NTB.

Although the NTB provincial government has adopted a policy to prevent child marriages through promulgating a circular letter on the maturity of marriage, the force of the circular letter does not have significant strength compared to regional regulations as a type of legislation recognised

\footnotetext{
${ }^{1}$ Suhadi,et.al., "Pencegahan Meningkatnya Pernikahan Dini dengan Inisiasi pembentukan Kadarkum di Dusun Cemanggal Desa Munding Kecamatan Bergas", Jurnal Pengabdian Hukum Indonesia (Indonesian Journal of Legal Community) JPHI, 01 (1), (2018), pp.1-40.

${ }^{2} \mathrm{http} / / /$ bappeda.ntbprov.go.id/sekilas-ipm/, accessed on January 13, 2019.
} 
in Article 7 of the law No. 12 of 2011 concerning the formation of legislation. Until now the regional regulations on the prevention of child marriage have not been owned by the NTB provincial government, so it can be assumed that the child marriage prevention policy does not have an adequate legal basis. In the end, the child marriage prevention policy in NTB was not able to get maximum results.

Another problem that characterises the high rate of child marriage is the existence of law number 1 of 1974 concerning marriage. It is law regulates the age of marriage with a minimum age of 16 years for women and 19 years for men is a serious legal issue because it provides an opportunity for citizens to carry out early marriages which are actually contrary to the development of the human maturity at this time which generally determine the minimum age a child is said to be 18 years as in the child protection law and the juvenile justice system law.

Until now the law number 1 of 1974 concerning marriage is still valid. As a legal instrument that has a higher position than regional regulations, this law is a stumbling block for local governments to make regional regulations regulate the maturation of early marriage in the region. The absence of regional regulations governing child marriages has made it difficult for local governments to reduce the number of child marriages in the region. In the end, the local government had difficulty increasing the human development index in the area.

Based on the above description, it is necessary to have a legal policy on prevention of child marriage in NTB that needs scientific studies as the basis for scientific legitimacy about the urgency of the existence of regulations on the prevention of child marriage. In this context, this research is important to be carried out as a basis for preparing academic manuscripts. Draft local regulations on the prevention of child marriage.

This article seeks to identify the root problems of child marriage in NTB and find a model for preventing child marriage in NTB. The results of the study later became the basis for the NTB provincial government, district/city governments in NTB and the central government in drafting and taking the policy to prevent child marriage at both the regional and national levels.

There are two problems in this study: first, What is the juridical problem in the policy of preventing the occurrence of child marriage in NTB? Second, What is the right and applicable policy model in preventing the occurrence of child marriage in NTB? 


\section{B. Research Method}

This research is normative legal research with a focus on studies on the policies that have been carried out and the research that will be conducted ${ }^{3}$. This research will focus on evaluating the policy of preventing child marriages that have been taken by the NTB provincial government. The research approach used is a normative approach and an empirical policy approach. The normative approach will examine the specific policies of legal policies that will be taken by the NTB provincial government in preventing child marriages. In line with policy research, the data sources to be used in this study are primary data and secondary data. Primary data is data obtained through in-depth interviews with competent respondents who have been predetermined (purposive sampling).

Collection of legal materials (library material) is carried out by reviewing and analysing library materials (reviewing legislation) whereas field data collection was carried out by intensive observation and direct interviews with respondents. Interviews are conducted in a structured manner based on a list of questions.

\section{Discussion}

\section{Prevention of Child Marriage: Perspective of Human Rights}

The issue of child marriage is a complex problem that intersects with issues of human rights, reproductive health, social issues, as well as legal issues. In line with these complex problems, this problem will be seen theoretically from the perspective of that complexity. The basic concept of human rights is the evolution of the concept of natural rights understood by thinkers in the 17th century. The concept of natural rights possessed by humans is a concept derived from the teachings of natural law. This thought was driven mainly by 17 th-century philosophers including John Locke, who developed until the 18th century as stated by French philosophers Montesquieu, Voltaire and JJ Rousseau.

Human rights that are rooted in human nature are rights that are born together with their existence as human beings and are their essential consequences and nature. Because of its nature, human rights are universal. Therefore human rights need respect. ${ }^{4}$ Human rights that we understand as natural rights have been expressed in various legal instruments both at international and national levels. In international legal instruments, we recognise the general declaration of human rights in 1948, the covenant of civil and political rights in 1966 and the covenant on economic, social and

\footnotetext{
${ }^{3}$ Nusa Putra dan Hendarman, Metode Penelitian Kebijakan, Bandung: Rosda, (2012), p.85.

${ }^{4}$ Gunawan Setiardja, Hak Asasi Manusia Berdasarkan Ideologi, Jakarta: Kanisius, (1993), pp. $1 \& 32$.
} 
cultural rights. International legal instruments, as outlined in various international conventions, according to James W. Nickel, ${ }^{5}$ have prominent features.

a. Human rights norms have a definite nature and have a high priority whose enforcement is mandatory

b. These rights have universality. It means that the rights possessed by humans are sole because they are human. This thought implies that characteristics such as race, gender, religion, social position, and citizenship are not relevant to question whether a person has or does not have human rights. Also implies that these rights can be applied throughout the world. One special feature of human rights that is in force now is that it is an international right. Compliance with similar rights has been seen as an object of legitimate attention and international action

c. Human rights are considered to exist by themselves and do not depend on the recognition and application in customary systems or legal systems in certain countries. This right may indeed not be an effective right until it is carried out according to law, but that right exists as a standard of argument and criticism that does not depend on the application of the law.

d. Human rights are seen as important norms. Although not entirely absolute and without exception, human rights have a strong position as normative considerations to be applied in conflicts with national norms that are contradictory, and to justify international actions taken for human rights. The rights outlined in the Declaration are not arranged according to priorities; its relative weight is not called. It is not stated that some of them are absolute. Thus the human rights described by the Declaration are philosophers call prima facie rights.

e. These rights imply obligations for individuals and the government. The existence of this obligation, as well as the rights associated with it, is deemed not to depend on the acceptance, recognition or application of it. Governments and people everywhere are required not to violate someone's rights, although the government of the person may also have the primary responsibility for taking positive steps to protect and uphold the rights of that person.

In Law Number 39 of 1999 concerning Human Rights Human Rights is defined as: "Human Rights are a set of rights attached to the nature of human existence as the creatures of God Almighty and are a gift that must be respected, upheld and protected by the state, law, the government and everyone for the sake of honour and protection of human dignity ". The UN

\footnotetext{
${ }^{5}$ James W. Nickel, Making Sense of Human RightsPhilosophical Reflection on the Universal Declaration of Human Rights, (1987), Cambridge, Mass: Harvard University Press, diterjemahkan oleh Titis Eddy Arini, Hak Asasi Manusia:Refleksi Filosofis atas Deklarasi Universal Hak Asasi Manusia, Jakarta: Gramedia Pustaka Utama, (1996), p. 51.
} 
International Organization defines human rights as follows: "human rights could be generally be defined as those rights which are inherent and without which we cannot live as human beings.

The expert's view has similarities to the juridical definition of human rights as stipulated in various legal documents. In the UN General Declaration of Human Rights, it is stated that human rights are inherent rights to humans. Similarly, the provisions contained in law number 39 of 1999 determine that human rights are a set of rights inherent in the nature of human existence as creatures of God Almighty and are a gift that must be respected, upheld and protected by the state, law, government and everyone for the sake of honour and the protection of human dignity.

Child marriage is a basic violation of the rights of girls. Child age marriage violates the Convention on the Rights of the Child (CRC), the Convention on the Elimination of All Forms of Discrimination against Women (CEDAW), and the Universal Declaration of Human Rights (UDHR). International human rights law states that marriage is a formal and binding agreement between adults. CEDAW states that child marriage should not be declared lawful (Article $16(2))^{6}$.

The CRC defines every person under the age of 18 as a child and has the right to all child protection. ${ }^{7}$ Child marriage 8 violating several human rights guaranteed by the CRC which include the following: (1) The right to education, child age marriage denies the child's right to education, play, and fulfil their potential because they can interfere with or end their education. (2) Rights to live free from violence and abuse (including sexual violence)9: Child age marriage increases girls' vulnerability to physical, sexual and mental violence. (3) Right to health10: Child age marriage can increase a girl's risk of illness and death associated with early pregnancy and childbirth. Furthermore, child age marriage limits girls' control of their bodies, including their sexual and reproductive abilities. (4) The right to be protected from exploitation ${ }^{11}$ : Child marriages often occur without children's consent or involve coercion that results in decisions ${ }^{12}$ aimed at taking advantage of

\footnotetext{
${ }^{6}$ The Convention on the Elimination of All Forms of Discrimination against Women. Article 16.

7 The Convention on the Rights of the Child, Article 1, p. 2.

8 The Convention on the Rights of the Child, Article 28 and 31, p. 8-9.

${ }^{9}$ The Convention on the Rights of the Child, Article 19 and 34, p. 5 and 10.; \& United Nations Children's Fund, Hidden in Plain Sight: A statistical analysis of violence against children, New York: UNICEF, (2014), pp. 131-133.

${ }^{10}$ The Convention on the Rights of the Child, Article 24, p. 7.

11 The Convention on the Rights of the Child, Article 36, p. 10.

${ }^{12}$ Halimatus Sakdiyah \& Kustiawati Ningsih, "Mencegah pernikahan dini untuk membentuk generasi berkualitas", Jurnal Masyarakat, Kebudayaan dan Politik, 26 (1), (2013), pp.3554.
} 
them or harming them rather than ensuring that their best interests are met. (5) The right not to be separated from their parents (separated) from their parents is against their will: ${ }^{13}$ Child marriage separates girls from their families and places them in alien relationships and environments where they may not be cared for or protected, and where they have no voice or power in decision-making on their own lives by limiting education, health, economic empowerment, opportunities to earn income in the future, security, activities and abilities of girls, and their status and role both within the home and in the community; Child marriage basically violates girls 'rights to equality and impedes girls' ability to live equally in society. To fulfil the rights of girls, there is a need for certainty that a girl is not married when she is a child.

\section{Child marriage and violation of children's rights}

Based on the description of human rights above, is associated with child marriage there will be various basic violations, especially for every person under the age of 18 as a child and entitled to all child protection. According to a study conducted by UNICEF and BPS ${ }^{14}$, several child rights are violated during child marriages. First, the right to education, secondly, the right to live free from violence and abuse (including sexual violence, the right to health, the right to be protected from exploitation, the right not to be separated from their parents (separated from their parents against their will).

Based on the definition submitted by BPS and UNICEF child age marriage is defined as "marriage conducted through civil, religious or customary law, and with or without recording or official approval where one or both partners are children under the age of 18 .

Child marriage involves one or both couples under the age of 18 , who are registered or not officially registered as well as under customary, religious or civil law (IPPF 2006). Child marriage is also known as forced marriage ${ }^{15}$ because children are still not able to take and give decisions related to couples and marriage. In this case, children lack knowledge of the life choices they have, so accepting marriage as part of their destiny

Based on the youth profile of NTB province in $2017^{16}$ stated that there were at least 5 (five) main factors causing child marriages, namely poverty,

13 The Convention on the Rights of the Child, Article 9, p. 3.

${ }^{14}$ BPS\&UNICEF, Kemajuan yang tertunda:Analisis Data Perkawinan Anak Di Indonesia, Jakarta: BPS, (2015), pp. 9-10.

15 Child marriage in South Asia: International and constitutional legal standards and jurisprudence for promoting accountability and change. 2013. https://www.reproductiverights.org//ChildMarriage_BriefingPaper, accessed on March 23, 2019.

${ }^{16}$ BPS Provinsi NTB, Profil Pemuda Provinsi NTB Tahun 2017, (2017), p. 34. 
low parental education level, culture ${ }^{17}$, changes in values in society, and lack of awareness and understanding of girls \& the influence of social media. Low-income family conditions make the potential for marrying children at an early age so great. The level of probability of low-income families is three times higher than for established families. The low level of education of parents who are also likely to have low-income families has an impact on making decisions to marry off their children at a younger age. Cultural aspects of society also influence the decision for the occurrence of child marriage. Some cultures tolerate child marriage. The low understanding of adolescents about the dangers of child marriage is also a factor that affects the occurrence of child marriage.

\section{Juridical Problems in Determining the Minimum Age of Marriage}

The causes of child marriages converge on issues, education, economics, culture and law. Therefore the approach to preventing child marriage in the region must be made by mitigating the various causes above. To reduce the causal factors that contribute to the occurrence of child marriages, there is a need for local government intervention through various policies in the region. Regional policies through legal instruments in the regions deal with legal issues that hamper efforts to prevent child marriages. Next, the author describes several legal instruments that hinder the prevention of child marriage.

a. Law Number 1 of 1974 concerning Marriage: A Stumbling Block

The stumbling block that is the obstacle to the marriage prevention policy is the existence of Law No. 1 of 1974 concerning Marriage regulating the age of marriage, which is still valid. Based on Law No. 1 of 1974 concerning Marriage, marriage age requirements are divided into 3 (three) categories:

1) 21 (twenty-one) years old to carry out marriage, a person who has not reached the age of 21 years must get permission from both parents.

2) Marriage is only permitted if the male has reached the age of 19 (nineteen) years, and the woman has reached the age of 16 (sixteen) years.

3) If a deviation from paragraph (1) of this article can request dispensation to the Court or other Officials appointed by both male and female parents.

Referring to the three categories of marriage age requirements above, the 19-year-old requirement for men and women has reached the age of 16

\footnotetext{
${ }^{17}$ Maman Abdullah, Studi Kasus Pernikahan "Merarik Sasak" di Pringgabaya (LombokNTB),(https://www.academia.edu/4701108/Studi_Kasus_Pernikahan_Merarik_Sasak_di_Prin ggabaya_Lombok-NTB_accesed 31Mei 2019.
} 
(sixteen) years and if not above the age indicates that the 19-year age requirement for men and women has reached the age of 16 (sixteen) years, it must be granted the status of a court or other official is a requirement that until now actually does not support efforts to prevent child marriages. Based on article 6 and article 7 above a woman has reached the age of 16 (sixteen) years and the age of 19 years for men then someone who will carry out marriage is considered to fulfil the requirements and marriage is considered legitimate.

Not just 16 years old for women and 19 years old men, prospective brides who are not yet 16 years old for women and 19 years old men may still carry out marriages if applying for dispensation to courts and courts there is a legitimate reason to provide dispensation. These two legal obstacles greatly contribute to the efforts of the regional government in taking legal policies to prevent child marriages. Local governments are legally illegitimate to take legal policies in the form of legal regulations in the regions such as regional regulations or governor's regulations for maturing or raising the age of marriage if law number 1 of 1974 concerning marriage is still valid. Regional regulations are not permitted to regulate material for regional regulations if the regulation contradicts the legal regulations above.

As long as law number 1 of 1974 concerning marriage is still valid, so long as the regional government does not have legal legitimacy to make regional regulations or governor regulations to increase the age of marriage, for example, up to the age of 18 (eighteen) years. Overcoming the legal problems on the road that can be taken by the regional government is to submit a request for a judicial review of law number 1 of 1974 concerning marriage or to convey aspirations to the DPR and the President to amend law number 1 of 1974 concerning marriage by increasing the age of marriage accordingly with the development of human psychology and the development of human health.

\section{b. Law Number 23 on 2014 of Regional Government}

Regarding the authority of the regional government to regulate the maturity of marriage in the provisions of Law number 23 on 2014 of regional government there are no rules specifically giving authority, but there are implicit authorities in the provisions of article 11 paragraph (2), article 12 paragraph 2 letters $h$ which states that population control and family planning are concurrent authorities, namely obligatory matters which are not basic services.

Because the content of the regional regulation must carry out the law orders above, the legal impact of the regional regulation as a statutory regulation which is hierarchically under law number 1 of 1974 concerning 
marriage, the local regulation may not conflict with the above laws. The policy of increasing early age which essentially increases the marriage age of brides who previously required the age of women aged at least 16 years and men at least 19 years as determined by law number 1 of 1974 concerning marriage, regional regulations or regional head regulations cannot change age requirements marriage is higher than marriage number 1 of 1974. This is the main obstacle to the policy of increasing the age of marriage in the region.

Legal barriers to child marriage prevention policies through increasing marital age are faced by other regions. Some regions have taken legal measures to prevent child marriages by ratifying regional regulations that specifically regulate this issue such as the Gunung Kidul Regent Regulation No. 30 of 2015 concerning prevention of child marriages, Regulation of regent Regent Kulon Progo No. 9 of 2016 concerning prevention of child marriage, and the Regulation of the Governor of Bengkulu No. 33 of 2018 concerning Prevention of Child Marriage. However, from the three laws and regulations there is no single provision that changes the marriage age requirements of 16 (sixteen) as stipulated in Article 7 paragraph (1) of Law Number 1 of 1974 concerning marriage by increasing the minimum marriage age requirement to a minimum of 18 (eight twelve) years or 19 (nineteen years).

This juridical obstacle has made the NTB provincial government not regulate the increasing age of marriage by using regional regulations or governor regulations. The government of NTB province has only used a Circular Letter Number: SE / 150/1138 / KUM 2014 regarding the maturation of marriage age. Although the Circular Letter Number: SE / 150/1138 / KUM 2014 concerning the maturation of the age of marriage have been enacted, it has weaknesses contained in it. First, the governor's Circular Letter is not one form of legislation as recognised in law number 12 of 2011 concerning the formation of legislation and law number 23 of 2014 concerning regional government. The status of the Circular Letter that is only binding into or merely a policy regulation (beleid regel) is what causes the governor's Circular Letter: SE / 150/1138 / KUM 2014 concerning the maturation of marriage age does not have binding legal force to regulate the maturity of marriage in NTB especially effective to prevent the occurrence of child marriages in NTB. Second, the ineffectiveness of the governor's circular Number: SE / 150/1138 / KUM 2014 concerning the maturation of the age of marriage. Regulation of marital requirements and administration has been regulated in legislation issued by the ministry of religion as the implementation of law number 1 of 1974 concerning marriage and not regulated in legislation issued by the ministry of internal affairs. The affairs of the requirements for maturing the age of marriage have been fully 
regulated by the ministry of religion which in the distribution of government affairs is religious affairs which are not handed over to the regions, so this is also a juridical obstacle faced by regional governments in regulating the maturity of marriage. This problem, according to the author, makes the governor's circular letter not have the effectiveness to be implemented in NTB Second, the ineffectiveness of the governor's circular Number: SE / 150/1138 / KUM 2014 concerning the maturation of the age of marriage. Regulation of marital requirements and administration has been regulated in legislation issued by the ministry of religion as the implementation of law number 1 of 1974 concerning marriage and not regulated in legislation issued by the ministry of internal affairs. The affairs of the requirements for maturing the age of marriage have been fully regulated by the ministry of religion which in the distribution of government affairs is religious affairs which are not handed over to the regions, so this is also a juridical obstacle faced by regional governments in regulating the maturity of marriage. This problem, according to the author, makes the governor's circular letter not have the effectiveness to be applied in NTB.

\section{c. The decision of the Constitutional Court No. 22/PUU/XV/2017}

Another legal issue that has become a barrier to regulating the maturity of marriage in NTB is the existence of the decision of the constitutional court No. 22 / PUU / XV / 2017 concerning judicial review of Law No. 1 of 1974 concerning Marriage. The Constitutional Court Decision read out on 12 December 2018 decided several things, first, grant the petition of the Petitioners; second, stating Article 7 (1) throughout the phrase "age 16 (sixteen) years in Law number 1 of 1974 concerning marriage contrary to the 1945 Constitution of the Republic of Indonesia and not having permanent legal force; third, stating the provisions of Article 7 paragraph (1) of Law Number 1 of 1974 concerning marriage still valid until changes are made in accordance with the grace period specified in this decision; fourth, ordering the legislators invite for a maximum period of 3 (three) years to amend Law No. 1 of 1974 concerning marriage, especially with regard to the minimum age for marriage for women; fifth, ordering the loading of this decision in the State news as appropriate; sixth, reject the request of the applicants for all.

The Constitutional Court's decision that is final and binding in the policy of child marriage prevention has serious obstacles that can be a legal stumbling block for the regional government. The author analyses the 3 (three) rules in the decision of the Constitutional Court judge which can be a legal obstacle to child marriage prevention policies, first; the ambivalence of the second ruling and the third ruling. In the second session stated, Article 7 (1) throughout the phrase "age 16 (sixteen) years in Law number 1 of 1974 
concerning marriage is contrary to the 1945 Constitution of the Republic of Indonesia and does not have permanent legal force and third amendment verdict stating the provisions of Article 7 paragraph (1) of Law Number 1 of 1974 concerning marriage is still valid until changes are made in accordance with the grace period specified in this decision.

The Constitutional Court's ruling on the second verdict stating Article 7 (1) throughout the phrase "age 16 (sixteen) years in Law number 1 of 1974 concerning marriage is contrary to the 1945 Constitution of the Republic of Indonesia and does not have permanent legal force if referring to the nature of the final and binding decision of the Constitutional Court, the provisions of Article 7 paragraph (1) concerning marital requirements for women aged 16 (sixteen) years in Law number 1 of 1974 concerning marriage are considered to be non-existent and have no legal force binding because it contravenes the 1945 Constitution of the Republic of Indonesia since the date it was read on 12 December 2018. This decision is, at first glance, an opportunity for local governments to adopt policies to prevent child marriages by increasing the age of marriage above 16 years. However, this decision does not have an impact when the third amendment states Article 7 paragraph (1) of Law Number 1 of 1974 concerning marriage which is still valid until changes are made by the time limit specified in this decision.

The existence of this petitum not only delayed the implementation of the decision on 12 December 2018 when the verdict was read, but also made this decision as if annulling the second ruling which had canceled article 7 paragraph (1) of law number 1 of 1974 concerning marriage by stating that Article 7 paragraph (1) Law Number 1 of 1974 concerning marriage is still valid until changes are made in accordance with the time limit specified in this decision. With the interpretation of a contrario it can be said article 7 paragraph (1) of law number 1 of 1974 even though there is a second ruling which invalidates article 7 paragraph (1) of marriage law number 1 of 1974 until now it is still valid as long as the government and DPR as the legislator does not amend article 7 paragraph (1) of law number 1 of 1974 concerning marriage. Two ways of establishing laws can do the mechanism for amending article 7 paragraph (1) of Law Number 1 of 1974 concerning marriage, namely by entering into amendments to Law No. 1 of 1974 concerning Marriage in the National Legislation Program 2019-2014 or by using authority the president to make government regulations in lieu of the law (perppu).

Second, decisions that are difficult to implement. The fourth ruling that instructs the legislators to make a change in the maximum period of 3 (three) years to Law Number 1 of 1974 concerning marriage, especially with regard to the minimum age for marriage for women, is difficult to do if you look at the formation process the law has a long process starting from planning, 
drafting, discussing, stipulating and promulgating for a long time, especially if according to the House of Representatives and the President consider changes to Law Number 1 of 1974 concerning marriage is not a priority bill that must be established. The President can use the machine for the formation of the emergency law (perpu) if according to the president he considers that the absence of article 7 paragraph (1) becomes a legal problem that has a forceful level of urgency. The next legal question that needs to be answered is how are the legal implications in the longest period of 3 (three) years that the DPR and the President make changes to Law Number 1 of 1974 concerning marriage? Does making amar number 2 the ruling apply or in other words Article 7 (1) throughout the phrase "age 16 (sixteen) years in Law number 1 of 1974 concerning marriage is contrary to the 1945 Constitution of the Republic of Indonesia and does not have permanent legal force automatically takes effect in 2021? Or are you waiting for changes in law number 1 of 1974 to be carried out by the president and the DPR or through an emergency law mechanism?

\section{Model of Prevention of Child Marriage Policy in NTB}

Legal obstacles faced by regional governments in taking the child marriage prevention policies outlined above show that there are serious obstacles that must be found a solution. The NTB government legal policy model through the governor's circular number: SE / 150/1138 / KUM 2014 concerning the maturation of marriage age has weaknesses contained in it and is not effective in preventing the occurrence of child marriage in NTB. Legally, the governor's circular letter Number: SE / 150/1138 / KUM 2014 concerning the maturation of marriage age does not have a binding capacity that is different from the regional regulation which can contain criminal sanctions and administrative sanctions which can be enforced. In this context, a new legal policy model is needed, which can replace the old legal policy as well as a reference for local governments in taking child marriage prevention policies.

The author offers a new policy model for the prevention of child marriage in NTB through transitional policies and post-transition policies. Policies during the transition period are carried out using a preventive and child protection approach. ${ }^{18}$ Policies in the post-transition period are carried out using the paradigm of increasing marital age and family quality.

\footnotetext{
${ }^{18}$ Chintya Dewi Saraswati, "The Modus Operandi of Children as the Offender in Committing Human (A study in Kepolisian Resor Kota Besar Surabaya)", Fiat Justisia Jurnal Ilmu Hukum, 13 (1), (2019), pp.75-86.
} 
a. Transitional Policy Model (2019-2021)

The transition policy model is intended as a legal policy taken by the NTB regional government when the transition period after the ruling of the constitutional court No. 22 / PUU / XV / 2017 concerning judicial review of Law No. 1 of 1974 concerning Marriage and waiting for the promulgation of the Act No. 1 of 1974 concerning marriage. The verdict stated that Article 7 paragraph (1) of Law Number 1 of 1974 concerning marriage is still valid until a change is made in accordance with the grace period specified in this decision and instructs the legislator for the longest period of time 3 (three) years of amending Law No. 1 of 1974 concerning marriage, especially with regard to the minimum age for marriage for women is the transition period given by the Constitutional Court to the DPR and the President to make laws to replace Law No. 1 of 1974 concerning Marriage. During the transition period (2018-2021) if it follows the logic of the decision above, there is very little room for regional governments to initiate legal policies by increasing the age of marriage above 16 years as opposed to article 7 paragraph (1) of Law No. 1 of 1974 concerning Marriage.

The policy to prevent child marriages during the transition period is carried out with a child protection approach and the prevention of child marriage. The approach to child protection is carried out using the child protection paradigm as adopted in the child protection law. This approach is intended as a legal strategy to prevent the occurrence of child marriages carried out by children who are not 18 (eighteen) years old and as a strategy indirectly increasing the age of marriage which is difficult to do because of juridical barriers in article 7 paragraph (1) of Law No. 1 of 1974 concerning Marriage.

\section{b. Legal Aspects}

The approach to preventing child marriage in the child protection paradigm is substantially efforts in the form of policies, programs, activities, and actions and other efforts carried out jointly between the regional government, parents, children and the community to prevent child marriage from occurring to reduce child marriage in NTB. ${ }^{19}$ The child protection paradigm is intended for all activities to guarantee and protect children's rights so that they can live, grow, develop and participate optimally according to human dignity and gain protection from the government.

Prevention of child marriage by using the child protection paradigm is based on the principles of child protection law such as the principle of non-

${ }^{19}$ Compare the definition of prevention of child marriage in the Bengkulu governor regulation No. 33 of 2018 regarding prevention of child marriage. 
discrimination, ${ }^{20}$ the best interests of the child, the right to life, survival, development and respect for the dignity of children, participation and empowerment.

The presence of child marriage prevention policies uses a comprehensive paradigm of goals, not only aspects of child protection, but also aspects of family, health, education, psychological, and economic quality. The goals of child prevention policies are first, realizing child protection and guaranteeing the fulfillment of children's rights so that they can live, grow, develop and participate optimally in accordance with human dignity, second, realizing quality children, noble and prosperous, ${ }^{21}$ third, preventing children drop out of school, prevent violence against children including child trafficking, ${ }^{22}$ fourth, prevent acts of domestic violence, fifth, improve women's reproductive health and quality of maternal and child health, sixth, reduce divorce rates, seventh, reduce maternal mortality, eighth, reducing infant and under-five mortality rates, and ninth, reducing poverty.

The range of child marriage prevention policies in NTB consists of several policies, namely prevention of child marriage, institutional strengthening, complaints if there are indications of child marriage, policies, strategies and programs, monitoring and evaluation, and financing.

In line with the above thoughts, what needs to be considered is the legal form of child marriage prevention policies in NTB, whether using regional regulations or governor regulations. According to researchers, the right form of legal policy in preventing child marriages in NTB is to use regional regulation instruments. The form of the local regulation was chosen based on the first consideration, the reason for legal needs by looking at the special conditions of the NTB already in the emergence of child marriages, but until now there has been no regional regulation that becomes a legal umbrella for local governments. Second, by using local regulations, the regional government can arrange criminal sanctions and administrative sanctions for the perpetrators and parents who conduct and order to conduct child marriages in the area. Local regulation is a legal instrument that is quite effective in preventing child marriages.

\footnotetext{
${ }^{20}$ Heri Setiawan.et.,al., "Gender Equality Issues in Optical Feminist Jurisprudence and Implementation in Indonesian", Fiat Justisia Jurnal Ilmu Hukum, (2018), 12 (4), pp.355367.

${ }^{21}$ Mohammad, "Perkawinan Anak Di Bawah Umur (Sebuah Kajian Perspektif Hukum Islâm Vis-a-Vis Hukum Positif di Indonesia)", Al-Ihkam: Jurnal Hukum dan Pranata Sosial, 6 (2) , (2011), pp.275-309.

${ }^{22}$ Mohamad Ismail Bin Mohamad Yunus, "Restorative Model: the Alternative Justice Response to the Victims of Sexual Violence", Fiat Justisia Jurnal Ilmu Hukum, 11 (1), (2017), pp.65-84.
} 


\section{c. Institutional Aspects}

From an institutional aspect, the prevention of child marriage in the area becomes the domain of authority of the Ministry of Religion, the National Family Planning Coordinating Board (BKKBN), and the Department of Protection and Empowerment of Women and Children and the participation of the community. These three institutions spearheaded efforts to prevent child marriages, first, the Ministry of Religion, especially officials from the religious affairs office (KUA). Being one of the frontline in the prevention of child marriage, because KUA officers who will deal directly with the community who apply for marriage dispensation for children under the provisions of Law No.1 of 1974 concerning Marriage and so far more than $90 \%$ of applications for marriage dispensation for children are accepted, and in recent years the number of applications submitted has increased ${ }^{23}$. Parents, relatives and children themselves usually submit applications for marriage dispensation for various reasons, but the most important reason for receiving marriage dispensation requests for children is because of a pregnancy that has occurred (married by accident). It is important to increase the understanding of KUA officers in this case marriage counsellors about efforts to prevent child marriage as part of efforts to build family quality. Secondly, the National Family Planning Coordinating Board (BKKBN) is an institution that is concerned with preventing child marriages and improving family quality and as the main implementer of the socialisation of family planning programs in Indonesia. As a national institution that has the main task of creating quality families, BKKBN has an important role to campaign for the prevention of early marriage. Through KB extension officers who have been in each village so far, these officers are the spearhead of the prevention of early marriage at the village level. Third, the Office for the Protection of Women and Children in every district/city and province is directed to mainstreaming child marriage prevention programs in every program for protecting women and children. Fourth, non-governmental organisations, the existence of non-governmental organisations that care about the protection of women and children become important in institutional aspects because NGOs can become partners of the government in advocating for policies and programs that are directly focused on preventing child marriages.

\section{d. Legal Culture Of Society Aspects}

Another important thing to do in the prevention of child marriage is to change the culture of the community. In the community, there is a false

\footnotetext{
${ }^{23}$ Evenhuis, Mark and Jennifer Burn, Just Married, Just a Child: Child marriage in the IndoPacific region, Melbourne: Plan International Australia, (2014), p. 26.
} 
assumption that it is still maintained that marrying an early child is better for the future of the child than allowing marriage in adulthood ${ }^{24}$. Though this assumption is wrong from the perspective of child rights, psychology, and children's health. Therefore, efforts need to be made to change the permissive legal culture of the community towards the marriage of children at an early age. According to the author, the law must be able to carry out its functions as a means to change people's behavior through social engineering (law as a tool of social engineering) as stated by Mochtar Kusumatmadja ${ }^{25}$ inspired by Roscou Pound's thinking that changed the legal culture of American society through Court Decisions. So it becomes important to increase school participation, increase access to higher education at the age of children and adolescents. Interventions on social and cultural norms that accept or preserve the practice of child marriage, through parents, extended families, teachers, religious leaders, traditional leaders.

\section{e. Post-Transitional Policy Model (post-2021)}

The advanced legal policy model of child marriage prevention policies in NTB transitions is post-transition policy. The purpose of the posttransition policy is to offer a legal policy model that can be taken by the NTB provincial government after the implementation of the Constitutional Court ruling in 2021. Based on the Constitutional Court's ruling in 2021, it can be estimated that the DPR and the President have already amended number 11974 about marriage. At that change, it can be ascertained that the age of marriage for women is no longer at least 16 years but already at the age of 19 for both men and women.

The new provisions regarding the minimum age for marriage in the amendment to law number 1 of 1974 concerning marriage after 2021 will provide legal opportunities for local governments to adopt more progressive policies in the prevention of marriages of their regional children. The government then not only regulates aspects of prevention of child marriages but also can regulate the increase in the age of marital requirements as stipulated in law number 1 of 1974 concerning new marriages.

In the policy of preventing child marriage after the amendment to law number 1 of 1974 concerning marriage not only regulates aspects of child marriage prevention, institutional strengthening, complaints if there are indications of child marriage, policies, strategies and programs, monitoring and evaluation, and financing, but also in the new policy namely increasing

${ }^{24}$ Sita Thamar van Bemmelen \& Mies Grijns, "Relevansi Kajian Hukum Adat: Kasus Perkawinan Anak Dari Masa Ke Masa", Mimbar Hukum, 30 (3), (2018), pp. 516-543.

${ }_{25}$ Mochtar Koesoemaatmadja, Konsep-konsep Pembangunan Hukum, Bandung: Alumni, (2002), p.25. 
the age of marriage from a minimum age of 16 years to age 19 for men and women.

Changes in law number 1 of 1974 concerning marriage certainly have an impact on the level of legal policy in the formation of laws and regulations in the regions. Legal instruments in the form of regional regulations used in the policy of preventing child marriages during the transition period can be continued to be implemented using the mechanism of change in the Regional Regulation in 2021. A new substance will be included in the policy to increase marital age by the amendment to number 11974 about marriage.

In the changes to the regional regulation, there has been a change in the paradigm of preventing child marriages from the protection approach, coupled with the marriage prevention paradigm by using a quality family formation paradigm. Prevention of marriage by increasing the age of marriage not only aims to protect children but also part of improving the quality of health and Indonesian families.

\section{Conclusion}

From the description of the discussion above, it can be concluded, firstly, that the prevention policy of child marriage in NTB not only has juridical obstacles in terms of the validity of the provisions of article 7 paragraph (1) of the marriage law that regulates the minimum age of marriage is 16 years for women, but also still has juridical constraints related to the legal policy of the regulation of child marital regulation in the content of regional regulations because the local regulation must not conflict with article 7 paragraph (1) of the marriage law which is still valid and other obstacles are not operational and effective decisions of the constitutional court No. 22 / PUU / XV / 2017 concerning judicial review of Law No. 1 of 1974 concerning Marriage because this decision only delayed the implementation of the Constitutional Court's decision in 2021 and was very dependent on legislative policy from the DPR and the President to amend Law No. 1 of 1974 concerning Marriage according to the order of the Constitutional Court's decision? Second, the appropriate and applicable policy model in preventing the occurrence of child marriages in NTB is done using the transitional policy model and post-transition policy. The transition policy is carried out by making regulations that regulate the prevention of child marriages by using the child protection paradigm, while post-transition policies are carried out using the family quality policy paradigm with a focus on increasing the age of marriage.

To realise the child marriage prevention policy model above, the author suggests several things that are legislative. First, the Republic of Indonesia Parliament, especially the Republic of Indonesia Parliament for the period 2019-2024 and the President should immediately follow up on Decision No. 
22 / PUU / XV / 2017 by taking legislative policies by entering the amendment bill to Law No. 1 of 1974 concerning Marriage into a national legislation program which is subsequently compiled, discussed and stipulated as law. Second, to respond to the dynamic dynamics of marital law and child protection, the NTB Governor and the NTB DPRD should immediately take legislation in the regions by including the draft regulation on the prevention of child marriages in the 2019 local regulation formation program and then compile and discuss it into regulations.

Acknowledgement

We express our gratitude to the Ministry of Research and High Education for funding this research, and we also thank for the LPPM of the Al-Azhar Islamic University Mataram, which fully supports this research.

\section{A. Books}

\section{Bibliography}

BPS Provinsi NTB. (2017). Profil Pemuda Provinsi NTB Tahun 2017. BPS\&UNICEF. (2015). Kemajuan yang Tertunda: Analisis Data Perkawinan Anak di Indonesia. Jakarta: BPS.

Evenhuis, Mark and Jennifer Burn. (2014). Just Married, Just a Child: Child marriage in the Indo- Pacific Region. Melbourne: Plan International Australia.

Koesoemaatmadja, Mochtar. (2002). Konsep-Konsep Pembangunan Hukum. Bandung: Alumni.

Nickel, James W. Making Sense of Human Rights Philosophical Reflection on the Universal Declaration of Human Rights. (1987). Cambridge, Mass.: Harvard University Press. Translated by Titis Eddy Arini. (1996). Hak Asasi Manusia: Refleksi Filosofis atas Deklarasi Universal Hak Asasi Manusia. Jakarta: Gramedia Pustaka Utama.

Nusa Putra dan Hendarman. (2012). Metode Penelitian Kebijakan. Bandung: Rosda.

Setiardja, Gunawan. (1993). Hak Asasi Manusia Berdasarkan Ideologi. Jakarta: Kanisius.

United Nations Children's Fund. (2014). Hidden in Plain Sight: A Statistical Analysis of Violence Against Children. New York: UNICEF.

\section{B. Journals}

Chintya Dewi Saraswati, "The Modus Operandi of Children as the Offender in Committing Human (A study in Kepolisian Resor Kota Besar Surabaya)", Fiat Justisia Jurnal Ilmu Hukum, 13 (1), (2019). https://doi.org/10.25041/fiatjustisia.v13no1.1508 . 
Halimatus Sakdiyah \& Kustiawati Ningsih, "Mencegah Pernikahan Dini Untuk Membentuk Generasi Berkualitas", Jurnal Masyarakat, Kebudayaan dan Politik, 26 (1), (2013).

Heri Setiawan.et.,al., "Gender Equality Issues in Optical Feminist Jurisprudence and Implementation in Indonesian", Fiat Justisia Jurnal Ilmu Hukum, 12 (4), (2018), https://doi.org/10.25041/fiatjustisia.v12no4.1386 .

Mohamad Ismail Bin Mohamad Yunus, "Restorative Model: the Alternative Justice Response to the Victims of Sexual Violence", Fiat Justisia Jurnal Ilmu Hukum, $11 \quad$ (1), (2017), https://doi.org/10.25041/fiatjustisia.v11no1.741 .

Mohammad, "Perkawinan Anak di Bawah Umur (Sebuah Kajian Perspektif Hukum Islâm Vis-a-Vis Hukum Positif di Indonesia)", Al-Ihkam: Jurnal Hukum dan Pranata Sosial, 6 (2), (2011).

Sita Thamar van Bemmelen \& Mies Grijns, "Relevansi Kajian Hukum Adat: Kasus Perkawinan Anak Dari Masa Ke Masa", Mimbar Hukum, 30 (3), (2018).

Suhadi,et.al., "Pencegahan Meningkatnya Pernikahan Dini dengan Inisiasi pembentukan Kadarkum di Dusun Cemanggal Desa Munding Kecamatan Bergas", Jurnal Pengabdian Hukum Indonesia (Indonesian Journal of egal Community) JPHI, 01(1), (2018).

\section{World Wide Web}

Abdullah, Maman. 2014. Studi Kasus Pernikahan "Merarik Sasak" di Pringgabaya (Lombok-NTB). (https://www.academia.edu/4701108/Studi_Kasus_Pernikahan_Merarik _Sasak_di_Pringgabaya_Lombok-NTB_accesed 31Mei 2019.

Child marriage in South Asia: International and constitutional legal standards and jurisprudence for promoting accountability and change. 2013,https://www.reproductiverights.org//ChildMarriage_BriefingPaper accessed on March 23, 2019.

http://bappeda.ntbprov.go.id/sekilas-ipm// accessed on January 13, 2019.

\section{Regulations}

Bengkulu Governor Regulation Number 33 on 2018 of Prevention of Child Marriage.

Law Number 1 on 1974 of Marriage.

Law Number 39 on 1999 of Human Rights.

The Convention on the Elimination of All Forms of Discrimination against Women.

The Convention on the Rights of the Child. 
